\title{
HARGA DIRI DENGAN DEPRESI PASIEN HIVIAIDS
}

Self Esteem With Hiv/Aids Patient Depression

\author{
Jek Amidos Pardede ${ }^{1}$, Johansen Hutajulu², Palti Elesson Pasaribu ${ }^{3}$ \\ ${ }^{1}$ Fakultas Farmasi dan IImu Kesehatan Universitas Sari Mutiara Indonesia \\ E-mail : jekpardedemi@gmail.com
}

\begin{abstract}
HIV / AIDS is a contagious disease by attacking white blood cells so that it can damage the human immune system. People with PLWHA certainly always get discriminatory acts from family, friends and relatives which can cause severe psychological effects such as depression. Depression is a period of disruption of human functions related to the natural feelings of sadness and its accompanying symptoms, including changes in sleep patterns and appetite, psychomotor, concentration, fatigue, hopelessness and helplessness, and the idea of suicide. If the patient has reached the stage of depression, the patient's self-esteem becomes low. The purpose of this study was to determine the relationship of self-esteem with depression in HIV / AIDS patients. The design of this research is the descriptive correlation with the cross-sectional approach. The population in this study amounted to 45 people with a sample of 31 people. The sampling technique was purposive sampling. The research instrument used was a questionnaire. The results of this study were analyzed by bivariate and univariate analysis. The results showed there was a relationship of self-esteem with depression in HIV / AIDS patients. The researchers concluded that when the patient was severely depressed the patient's self-esteem would be low which was marked by $p$-value $=0,000(p=0.05)$. It is recommended for hospitals to make routine counselling schedules by involving nurses in their implementation.
\end{abstract}

Keywords : Depression, Self-Esteem, HIVIAIDS

\begin{abstract}
ABSTRAK
HIVIAIDS merupakan penyakit menular dengan cara menyerang sel darah putih sehingga dapat merusak system kekebalan tubuh manusia. Teman maupun kerabat yang dapat menimbulkan dampak psikologis yang berat seperti depresi. Depresi merupakan suatu masa terganggunya fungsi manusia yang berkaitan dengan alam perasaan yang sedih dan gejala penyertanya, termasuk perubahan pada pola tidur dan nafsu makan, psikomotor, konsentrasi, kelelahan, rasa putus asa dan tak berdaya, serta gagasan bunuh diri. Apabila pasien telah sampai ke tahap depresi, maka harga diri pasien pun menjadi rendah. Tujuan penelitian ini adalah untuk mengetahui hubungan harga diri dengan depresi pasien HIVIAIDS. Desain penelitian ini adalah deskriptif korelasi dengan pendekatan cross sectional. Populasi dalam penelitian ini berjumlah 45 orang dengan jumlah sampel 31 orang. Teknik pengambilan sampel dengan purposive sampling. Instrumen penelitian yang digunakan adalah kuesioner. Hasil penelitian ini dianalisis dengan analisis bivariat dan univariat. Hasil penelitian menunjukkan ada hubungan harga diri dengan depresi pada pasien HIVIAIDS. Peneliti menyimpulkan bahwa ketika pasien depresi berat maka harga diri pasien akan menjadi rendah yang ditandai dengan pvalue $=0,000(p=0,05)$. Disarankan bagi rumah sakit agar membuat jadwal konseling secara rutin dengan melibatkan perawat dalam pelaksanaannya.
\end{abstract}

Kata Kunci : Depresi, Harga Diri, HIVIAIDS

\section{PENDAHULUAN}

Secara global tahun 2016 jumlah Orang Dengan HIVIAIDS (ODHA) ada 36,7 juta dengan 2,2 juta kasus HIV dan sekitar 1,5 juta orang meninggal karena AIDS. Kasus HIV di Asia Tenggara dari tahun 2000-2015 terus mengalami peningkatan, dari 2,9 juta menjadi 3,5 juta penderita (Kemenkes RI, 2017). Jumlah kasus yang tercatat bulan Oktober 2005 Desember 2017 sebanyak 2.528 yang terdiri dari 859 kasus HIV dan AIDS sebesar 1.669, serta meninggal dunia sebanyak 701 orang (UNAIDS, 2017).
HIVIAIDS telah menjadi masalah kesehatan tertinggi dunia, hingga saat ini HIVIAIDS telah menelan korban lebih dari 34 juta jiwa di Afrika. Pada tahun 2014 ada 1,2 juta orang meninggal karena terkena HIVIAIDS di Afrika. Hingga akhir 2014 ada sekitar 36,9 juta orang hidup dengan HIVIAIDS, Afrika menjadi wilayah paling dampak terkena penyakit HIVIAIDS, afrika memiliki 25.8 juta orang hidup dengan HIVIAIDS dan Afrika menyumbang hampir $70 \%$ dari total global infeksi HIVIAIDS. Di Asia tenggara pada tahun 2015, Indonesia merupakan penduduk yang terinfeksi HIVIAIDS, dengan usia 15 49 tahun mencapai 0,5 dari 1000 populasi. Sementara penduduk Myanmar, Malaysia dan 
Vol. 11 No. 012020

e-issn : 2622-0148, p-issn : 2087-0035

Vietnam terjangkit mencapai 0.3 dari 1000 populasi. Thailand dan Laos terjangkit HIVIAIDS mencapai 0.2 dari 1000 populasi. Dan terendah yang terinfeksi HIVIAIDS yaitu Filipina dan Kamboja dengan prevalensi 0.1 dari 1000 populasi.

Menurut data Kemenkes RI, kasus HIV/AIDS di Indonesia pada tahun 2017 sebanyak 330.152 orang, dengan terinfeksi HIV sebanyak 242.699 orang dan yang mengalami AIDS sebanyak 87.453 orang. Urutan prevalensi HIVIAIDS yang cukup tinggi di provinsi yang ada di Indonesia antara lain DKI Jakarta, Jawa Timur, Papu, Jawa Barat, Jawa Tengah, Bali dan Sumatera utara.

Sumatera Utara berada di urutan ke 7 dari 10 provinsi di Indonesia dengan data kasus terbesar HIVIAIDS sebanyak 17.333 orang dengan presentase yang terinfeksi HIV sebanyak 13.454 orang dan yang telah terdiagnosa AIDS sebanyak 3.879 orang. Kota Medan menjadi daerah tertinggi untuk kasus HIVIAIDS dari seluruh Kabupaten/Kota di Sumatera Utara dengan jumlah penderita sebanyak 2.616 kasus dengan prensentase HIV sebanyak 1.535 orang dan AIDS sebanyak 1.081 orang.(Kemenkes RI, 2017).Pasien HIVIAIDS di RSUP H.Adam Malik Medan selama tiga tahun terakhir mengalami peningkatan setiap tahunnya. Pada tahun 2015 pasien dengan HIVIAIDS sebanyak 485 orang, pada tahun 2016 sebanyak 524 orang dan pada tahun 2017 sebanyak 584 orang. Pada tahun 2018 terakhir ini penyakit HIVIAIDS mengalami penurunan menjadi 541 pasien.

Orang Dengan HIVIAIDS (ODHA), dan hal tersebut harus segera mendapatkan penanganan. Perlakuan diskriminatif dapat berasal dari keluarga sendiri, teman dan kerabat, masyarakat sekitar, ataupun dari pemerintah.Stigma dan deskriminasi menimbulkan dampak psikologi yang berat bagaimana ODHA memandang diri mereka. Kondisi ini dapat mendorong terjadinya depresi, kurang penghargaan diri, keputusasaan, bahkan keinginan bunuh diri atau merusak dirinya. Kurangnya dukungan dari lingkungan (dukungan material, informasional, emosional, sosial, atau spiritual) akan membuat kualitas hidup ODHA memburuk (Wahyuningsih \& Novianto, 2017).

Menurut World Health Organization (Utami, Liza, \& Ashal, 2018). bahwa depresi merupakan suasana hati dan tanggapan emosional dalam menanggapi respon kehidupan, dapat menyebabkan gangguan yang serius dan berdampak pada tempat kerja, sekolah maupun keluarga, bahkan bunuh diri bisa dilakukan akibat dari depresi, Hasil sidang World Health Assembly pada 2018 menyatakan depresi ditingkat negara semakin meningkat secara global. Depresi merupakan salah satu bentuk yang ditandai dengan kemurungan, kelesuan, tidak bergairah, putus asa, dan tidak berguna (Wandono, 2017), depresi juga dapat menonaktifkan hubungan fungsional, sosial dan fisik, dan meningkatkan angka bunuh diri (Rahmawati, Arneliwati, \& Elita, 2015). Gejala paling khas sering terjadi saat berduka cita dan individu yang melaporkan keadaan depresi, seperti mengalami kesedihan, insomnia, penurunan nafsu makan.

Beberapa peneliti telah mencatat bahwa kesedihan tidak selalu menghasikan gejala kognitif depresi, seperti halnya harga diri rendah atau perasaan tidak berharga (Siboro, 2013). Bahkan sebanyak 1.752 kasus dengan depresi didiagnosis klinis atau pengguna anti depresan, yakni diagnosis depresi meningkat resiko sebanyak 3,6 kali lipat (Marsasina \& Fitrikasari, 2016). Menurut Ibrahim, H, Rahayuwati, \& Nurmalisa, (2017), menunjukan gangguan emosional sebesar $6 \%$ usia produktif mulai dari 15 tahun ke atas atau sekitar 14 juta orang mengalami gejala depresi. Hapsari, Elyana., Sarjana, Widodo \& Sofro, (2016), angka kejadian depresi di Indonesia sebanyak 706.689 jiwa, provinsi yang memiliki prevalensi angka kejadian depresi pada peringkat pertama yaitu provinsi Jawa Barat sebanyak 130.528 jiwa, Jawa Timur sebanyak 111.879 jiwa, jawa tengah sebanyak 95.461 jiwa dan Sumatera Utara menduduki peringkat keempat dengan jumlah sebanyak 36.147 jiwa. Angka kejadian depresi pada ODHA di Sumatera Utara sebanyak $55,8 \%$ dengan pembagian depresi ringan $25,6 \%$, depresi sedang $11,6 \%$, depresi berat $4,7 \%$, dan depresi sangat berat $14 \%$. Depresi terbanyak ditemukan pada usia 20-39 tahun $(83,3 \%)$. Sehingga dari harga diri yang dialami oleh seseorang akan mengalami perubahan menjadi depresi dan perubahan kebiasaan sehari-hari (Haryanto, Wahyuningsih, \& Nandiroh, 2015).

Harga diri yang tinggi dikaitkan dengan kecemasan yang rendah, efektif dalam kelompok dan penerimaan orang lain terhadap dirinya, sedangkan masalah kesehatan dapat menyebabkan harga diri, sehingga harga diri dikaitkan dengan hubungan interperonal yang buruk dan beresiko terjadinya depresisehingga perasaan negatif mendasari hilangnya kepercayaan diri dan harga diri individu dan menggambarkan gangguan harga diri (Wandono, 2017).

Adapun faktor penyebab dari gangguan harga diri yang pertama yaitu faktor predisposisi meliputi faktor yang mempengaruhi harga diri seperti penolakan dari orang tua, harapan dan ideal diri yang tidak bisa tercapai, selalu menemui kegagalan, tanggung jawab personal yang kurang serta ketergantungan terhadap 
Vol. 11 No. 012020

e-issn : 2622-0148, p-issn : 2087-0035

orang lain, faktor performa peran seperti peran gender, tuntutan kerja dan budaya yang dapat mempengaruhi, sedangkan faktor identitas diri meliputi tekanan yang disebabkan dari orang - orang terdekat seperti orang tua yang kurang percaya akan dirinya, tekanan dari kelompok sebaya dan perubahan struktur sosial, yang kedua yaitu faktor stresr pencetus dapat terjadi diakibatkan oleh truma seperti penganiyaan seksual dan pskosial atau ancaman yang dapat mengganggu kehidupan, ketegangan peran yang mengakibatkan individu frustasi atas posisi yang didapatkan. Dengan gangguan harga diri, seseorang akan menghadapi suasana hati dan ingatan tentang masa lalu yang negatif dan lebih rentan mengalami depresi ketika menghadapi stress karena pola pikir yang buruk tentang diri sendiri, tujuan hidup yang tidak jelas, dan masa depan yang lebih pesimis, semakin rendah harga diri seseorang akan lebih berisiko terkena gangguan kepribadian (Betty et al. 2016 dalam Wandono, 2017).

Berdasarkan data didapatkan di RSUP H. Adam Malik Medan jumlah penderita HIVIAIDS rawat inap pada tahun 2018 sebanyak 541 pasien. Hasil wawancara yang dilakukan peneliti dengan 8 orang pasien penderita HIVIAIDS di RSUP H. Adam Malik Medan 5 orang di antaranya menyatakan bahwa yang terkena HIVIAIDS akan memicu mereka depresi dan menimbulkan kematian yang disebabkan penyakit yang dideritanya saat ini, dan 3 orang merasa depresi karena jika sudah terjadi penyakit HIVIAIDS sangat sulit di sembuhkan bahkan kemungkinan tidak bisa disembuhkan.

\section{METODE PENELITIAN}

Desain penelitian ini adalah Deskriptif Korelasi dengan pendekatan cross- sectional, Populasi dalam penelitian ini adalah seluruh pasien HIVIAIDS di RSUP H. Adam Malik Medan Tahun 2018 berjumlah 45 orang perbulannya. Teknik pengambilan sampel pada penelitian ini adalah Accidental sampling. Yaitu sebanyak 31 orang yang mengalami HIVIAIDS. Kriteria pengambilan sampel: Pasien yang telah terdiagnosa AIDS, bisa baca tulis, dapat berkomunikasi dan berbahasa Indonesia dengan baik, tidak dalam keadaan koma, bersedia menjadi responden. Responden yang dijadikan sampel dari beberapa ruangan yang ada di RSUP H. Adam Malik Medan. Penelitian ini menggunakan alat pengumpuan data menggunakan kuesioner harga diri 10 pernyataan dengan cronbach alpha yaitu 0,877 dan kuesioner DASS sebanyak 14 pernyataan cronbach alpha yaitu 0,91. Uji statistik yang digunakan dengan Spearman Corelation.

\section{HASIL}

Tabel 1.

Distribusi Frekuensi dan Persentase Berdasarkan Karakteristik Responden di RSUP H. Adam Malik

\begin{tabular}{lcc}
\hline Karakteristik & $\mathrm{n}$ & $\%$ \\
\hline Jenis Kelamin & 23 & 77,4 \\
- - Laki-laki & 7 & 22,6 \\
- Perempuan & & \\
\hline Usia (tahun) & 28 & 90,3 \\
- 21-40 Tahun & 3 & 9,7 \\
- >40 Tahun & & \\
\hline Pekerjaan & 1 & 3,2 \\
- Buruh & 3 & 9,7 \\
- Dagang & 5 & 16,1 \\
- IRT & 2 & 6,5 \\
- Tani/Nelayan & 3 & 9,7 \\
- Sopir/Kernet & 17 & 54,8 \\
- Wiraswasta & & \\
\hline Status Kawin & 4 & 12,9 \\
- Belum Menikah & 4 & 12,9 \\
- Cerai Hidup & 4 & 12,9 \\
- Cerai Mati & 19 & 61,3 \\
- Menikah & & \\
\hline
\end{tabular}


Vol. 11 No. 012020

e-issn : 2622-0148, p-issn : 2087-0035

Berdasarkan Tabel 1 dapat dilihat bahwa jenis kelamin mayoritas laki-laki sebanyak 23 responden $(77,4 \%)$, usia mayoritas $21-40$ tahun sebanyak 28 responden $(90,3 \%)$, pekerjaan mayoritas wiraswasta sebanyak 17 responden $(54,8)$ dan status kawin mayoritas menikah sebanyak 19 responden $(61,3 \%)$.

Tabel 2

Persentase Frekuensi Harga Diri Pasien HIVIAIDS

\begin{tabular}{lcc}
\hline Harga Diri & $\mathrm{n}$ & $\%$ \\
\hline Tinggi & 24 & 77,4 \\
Rendah & 7 & 22,6 \\
\hline
\end{tabular}

Berdasarkan tabel 2 dapat dilihat bahwa harga diri pasien HIVIAIDS mayoritas tinggi yaitu $(77,4)$.

Tabel 3

Persentase Frekuensi Depresi Pasien HIVIAIDS

\begin{tabular}{lcc}
\hline Depresi & $\mathrm{n}$ & $\%$ \\
\hline Ringan & 17 & 54,8 \\
Sedang & 11 & 35,5 \\
Berat & 3 & 9,7 \\
\hline
\end{tabular}

Berdasarkan tabel 3 dapat dilihat bahwa depresi pasien HIVIAIDS di RSUP H. Adam Malik, mayoritas rendah yaitu $(54,8)$.

Tabel 4

Hubungan Harga Diri Dengan Depresi Pasien HIVIAIDS

\begin{tabular}{|c|c|c|c|c|c|c|c|c|c|c|}
\hline \multirow[t]{3}{*}{ Harga Diri } & \multicolumn{6}{|c|}{ Depresi } & \multirow{2}{*}{\multicolumn{2}{|c|}{ Total }} & \multirow[t]{3}{*}{$r$} & \multirow[t]{3}{*}{$p$} \\
\hline & \multicolumn{2}{|c|}{ Ringan } & \multicolumn{2}{|c|}{ Sedang } & \multicolumn{2}{|c|}{ Berat } & & & & \\
\hline & $\mathrm{n}$ & $\%$ & $\mathrm{n}$ & $\%$ & $n$ & $\%$ & $n$ & $\%$ & & \\
\hline Tinggi & 17 & 54,8 & 7 & 20 & 3 & 9.7 & 27 & 84,5 & & \\
\hline Rendah & 0 & 0 & 4 & 15,5 & 0 & 0 & 4 & 15,5 & 0.603 & 0.000 \\
\hline Total & 17 & 54,8 & 11 & 35,5 & 3 & 9,7 & 31 & 100 & & \\
\hline
\end{tabular}

Dari tabel 4 dapat dilihat bahwa harga diri tinggi $(84,5 \%)$ yang memiliki depresi ringan $(54,8 \%)$, depresi sedang $(15,5 \%)$, dan depresi berat $(9,7 \%)$. Harga diri rendah (15,5\%), dengan depresi sedang $(15,5 \%)$.

Dari hasil uji statistik menggunakan uji Spearman Corellation, hasil diketahui $p$ value $=0.000(p<0.05)$, artinya ada hubungan yang signifikan antara harga diri dengan depresi pasien HIVIAIDS di RSUP $\mathrm{H}$. Adam Malik dan nilai $r=0.603(0.56-1,00=$ kuat $)$ artinya semakin tinggi harga diri maka semakin rendah depresi pasien pasien HIVIAIDS di RSUP H. Adam Malik.

\section{PEMBAHASAN}

\section{Harga Diri}

Hasil penelitian yang didapat bahwa karakteristik responden berdasarkan jenis kelamin mayoritas laki- laki sebanyak 23 responden (77,4\%). Distribusi jenis kelamin responden yang paling banyak dalam penelitian ini adalah pria. Hasil ini sesuai dengan (Riskesdas, 2017), jumlah penderita terbanyak adalah pria. Dari hasil ini dapat dilihat laki-laki lebih rentan terkena infeksi HIV karena berdasarkan cara penularan, laki-laki lebih banyak terpapar dengan kejadian infeksi HIV yakni melalui tiga cara utama meliputi: penasun, homoseksual, dan heteroseksual atau seks bebas.

Apabila dilihat dari segi usia responden dalam penelitian ini mayoritas antara umur 21-40 tahun. Pada usia dalam tahap usia produktif, yang artinya pada tahap usia ini kebanyakan melakukan kenakalan remaja salah satunya seks bebas. Pertama melakukan seks bebas mungkin masih belum merasakan gejala yang akan ditimbulkan oleh virus HIV, namun lambat laun akan merusak sel dalam tubuh. Waktu yang dibutuhkan virus HIV 
Vol. 11 No. 012020

e-issn : 2622-0148, p-issn : 2087-0035

selama 10 tahun baru dikatakan sebagai ODHA (orang dengan HIVIAIDS). Sehingga setelah terdeteksi sebagai ODHA baru merasakan gejala yang muncul dari virus HIV. Pada tahap usia ini memang sangat rentan sekali terkena HIV, hal ini dikarenakan pada tahap usia ini adalah tahap ingin tahu dan ingin mencoba sangat besar.

Hasil penelitian ini merupakan hal yang memungkinkan terjadi bila dilihat dari data status perkawinan responden dimana sebanyak 19 responden $(61,3 \%)$ sudah menikah sehingga masih aktif melakukan hubungan seksual dengan pasangannya. Pada orang yang menikah merupakan hal yang wajar melakukan hubungan seks tidak menggunakan pengaman (kondom) karena muncul persepsi di masyarakat bahwa merupakan hal tidak etis bila melakukan hubungan seks dengan suami/istrinya menggunakan kondom meskipun tahu beresiko untuk menularkan HIV pada pasangannya ( Benerjee \& Sharma, 2007).

Berdasarkan variabel harga diri responden sebanyak 24 responden $(77,4 \%)$ memilki harga diri yang tinggi dalam kehidupannya. Hal ini sesuai dengan hasil kuesioner yang telah diisi oleh responden, mereka mengatakan bahwa merasa puas dengan dirinya, masih memiliki sejumlah kualitas pada dirinya, merasa dirinya masih berharga meskipun dalam keadaan sakit. Dalam proses kehidupan sehari-hari, harga diri merupakan aspek yang krusial dalam membentuk suatu perilaku. Orang dengan harga diri yang tinggi cenderung bersikap positif terhadap permasalahan yang dihadapinya, sebaliknya orang yang dengan harga diri rendah akan menghadapi suatu masalah secara emosional, tergesa-gesa, dan kadang tidak memikirkan dampak di masa yang datang (Sternke, 2010).

Pasien HIV AIDS sejak pertama kali datang untuk deteksi dini sudah diberikan konseling (Cichocki, 2009). Pemberian konseling bertujuan untuk menyiapkan mental dan psikologis pasien sehingga apabila hasil pemeriksaan dinyatakan positif maka pasien sudah siap menerima kenyataan tersebut. Menurut penjelasan perawat penanggung jawab klinik pelayanan HIV AIDS di di RSUP $\mathrm{H}$. Adam Malik, konseling dapat diberikan oleh dokter, perawat, atau psikolog selama kurang lebih 30 menit untuk setiap pasien. Konseling digunakan juga untuk mengantisipasi penurunan mental dan psikologis pasien karena orang dengan menderita HIV AIDS akan memperoleh stigma yang negatif dari masyarakat karena HIV AIDS dianggap penyakit kotor. Penderita HIV AIDS pun harus harus siap mendapat perlakuan diskriminatif dan diasingkan oleh masyarakat. Kelompok dukungan sebaya (KDS) memiliki peran vital dalam peningkatan harga diri penderita HIV AIDS.

Melalui KDS permasalahan-permasalahan yang muncul setelah status ODHA disandang dapat diatasi bahkan dicegah. Melalui KDS para penderita HIV AIDS dapat saling bertukar pengalaman dan dukungan sehingga mereka dapat mengikuti program pengobatan dan perawatan secara rutin dan teratur. Oleh karena itu dukungan psikologis terhadap pasien HIV AIDS perlu terus diberikan sehingga penderita HIV AIDS memiliki status mental dan konsep diri yang sehat.

Penelitian lain juga yang mendukung oleh Siboro (2013) menunjukan hubungan yang positif dari dukungan keluarga terhadap keberfungsian sosial orang dengan HIVI AIDS. (Harefa dkk, 2012) mendapatkan adannya hubungan dukungan keluarga dengan harga diri ODHA. Dari $66,7 \%$ responden yang memiliki dukungan keluarga baik, sebanyak $60,8 \%$ memiliki harga diri positif dan hanya 6,9\% yang memiliki harga diri negatif. Hasil penelitian $\mathrm{Li}$ et al, (2006) terhadap 30 penderita HIVIAIDS menunjukan semua partisipan penelitian sangat membutuhkan bantuan dan sumber utama dukungan yang berasal dari keluarga. Dukungan keluarga termasuk bantuan keuangan, dukungan dalam mengungkapkan penyakit, aktivitas perawatan sehari-hari, dan dukungan psikologis. Penelitian menggambarkan bahwa dukungan yang disediakan keluarga dapat memberikan efek positif pada penderita HIVIAIDS, sehingga penting melibatkan keluarga dalam intervensi HIVI AIDS.

Peneliti berasumsi bahwa pasien dengan HIVIAIDS masih memiliki harga diri yang tinggi sama halnya dengan orang yang belum terkena penyakit HIVIAIDS. Tingginya harga diri pasien HIVIAIDS berawal dari dukungan orang disekitarnya dan terlebih di RSUP H. Adam Malik sering dilakukannya konseling kepada pasien. Untuk itu, perlu dukungan dan motivasi lagi kepada pasien baik dari keluarga sendiri maupun dari orang lain.

\section{Depresi}

Hasil penelitian derajat keparahan depresi pada penelitian ini didapatkan ialah depresi ringan $54,8 \%$, depresi sedang $35,5 \%$ dan depresi berat $9,7 \%$. Hal ini sesuai dengan hasil kuesioner depresi, bahwa sebagian responden mengatakan masih melihat positif dari suatu kejadian, sedikit pesimis, jarang merasa sedih dan depresi serta merasa masih layak dimasyarakat. Ditambah lagi dengan pernyataan merasa masih ada masa depan dan hidup yang berarti. Hal inilah yang masih memotivasi pasien HIVIAIDS sehingga mereka tidak mudah untuk 
Vol. 11 No. 012020

e-issn : 2622-0148, p-issn : 2087-0035

depresi dan ditambah lagi dengan kuatnya dukungan dari keluarga maupun orang terdekatnya.

Hal ini sesuai dengan penelitian (Unnikrishnan, 2012) menyebutkan pasien HIVIAIDS yang mengalami depresi sebanyak 20-39\%. Kurang maksimalnya pemanfaatan pelayanan poli VCT dan dukungan dari masyarakat dapat menyebabkan tingginya angka depresi. Ada sejumlah faktor psikososial yang diprediksi sebagai penyebab gangguan mental pada seseorang yang pada umumnya berhubungan dengan kehilangan. Faktor psikososial tersebut adalah hilangnya peranan sosial, hilangnya otonomi, kematian teman atau sanak saudara, penurunan kesehatan, peningkatan isolasi diri, keterbatasan finansial, dan penurunan fungsi kognitif.

Penelitian ini juga didukung oleh penelitian (Yaunin. dkk, 2013) yang dilakukan di RSUP Dr. M. Djamil Padang dengan judul Kejadian gangguan depresi pada pasien HIVIAIDS. Dari 43 sampel penelitian didapatkan depresi ringan sebanyak $25,6 \%$, depresi sedang $11,6 \%$ dan depresi berat sebanyak $4,7 \%$. Penelitian ini juga didukung oleh (Bhavna, 2015) terhadap 66 penderita HIVIAIDS yang mendapatkan hasil lebih dari $50 \%$ penderita tidak mengalami depresi. Namun, hal ini bertentangan dengan peneitian (Cichocki, 2009) yang menyatakan bahwa pasien HIVIAIDS sangat rentan mengalami depresi, dan depresi menjadi masalah psikososial terbesar yang dihadapi ODHA. Tidak ada depresinya sebagian besar penderita HIVIAIDS mungkin disebabkan salah satunya karena adanya peran dukungan sosial. Salah satu bentuk dukungan sosial yang ada yaitu dukungan keluarga dan orang terdekat pasien. Hai ini sesuai dengan penelitian oleh (Kanniappana et al., 2007) yang menyebutkan bahwa ODHA yang depresi atau stres membutuhkan dukungan baik emosional, informasi dan material. ODHA sering dijumpai keluarga maupun orang terdekatnya sehingga ODHA merasa tidak sedih dan merasa masih dianggap dalam keluarga.

Peneliti berasumsi bahwa pasien dengan HIVIAIDS selalu depresi dengan keadaannya, namun tingkat depresi yang dialami masih dalam kategori ringan. Depresi mengakibatkan kondisi pasien akan semakin memburuk jika tidak cepat ditangani. Cara menangani depresi pasien yaitu dengan selalu memberi dukungan dan motivasi yang kuat agar pasien tidak merasa depresi selama menjalani perawatan.

\section{Hubungan Harga Diri Dengan Depresi Pasien HIVIAIDS}

Dari hasil penelitian yang didapat, diketahui bahwa dengan harga diri tinggi yaitu $77,4 \%$ memiliki depresi ringan $54,8 \%$. Dari hasil ini terlihat bahwa semakin tinggi harga diri pasien tentunya sangat berpengaruh pada depresi pasien saat menjalani perawatan karena merasa masih mempunyai harga diri yang tinggi dan harapan yang positif serta hubungan dengan keluarga masih baik/masih diperhatikan oleh keluarga.

Hal ini sesuai dengan teori Sternke (2010) yang mengatakan bahwa Orang dengan harga diri yang tinggi cenderung bersikap positif terhadap permasalahan yang dihadapinya, sebaliknya orang yang dengan harga diri rendah akan menghadapi suatu masalah secara emosional, tergesa-gesa, dan kadang tidak memikirkan dampak di masa yang datang.

Dari data demografi responden didapatkan bahwa status perkawinan mayoritas menikah $(61,3 \%)$. Perhatian dari pasangan (suami/istri) termasuk dalam kelompok dukungan internal yang sangat membantu mempertahankan harga diri pasangannya yang dirawat. (Sudrajat, 2012) dalam penelitianya menyatakan bahwa dukungan yang baik dipengaruhi oleh dukungan dari orang yang sangat berarti atau orang yang dekat dengan pasien dalam hal ini suami atau istri dan anak-anak pasien.

Dalam penelitian ini juga didapatkan hasil harga diri tinggi $54,8 \%$ dengan depresi sedang sebesar $35,5 \%$ dan depresi berat sebesar $9,7 \%$. Hal ini sesuai dengan pernyataan responden melalui pengisian kuesioner bahwa sebagian responden masih merasa sedih dan depresi dengan penyakitnya, merasa sepertinya tidak kuat lagi untuk melakukan suatu kegiatan, merasa tidak layak serta merasa dirinya tidak berharga. Menurut teori ( Widayati \& Murtaqib, 2016) mengatakan bahwa perlakuan diskriminatif yang berasal dari keluarga, teman serta masyarakat dapat menimbulkan dampak psikologi yang berat pada ODHA. Kondisi ini dapat mendorong terjadinya depresi, kurang harga diri, keputusasaan bahkan sampai bunuh diri.

Berdasarkan hasil uji statistik Spearman Correlation didapatkan nilai $p$ value $=0.000(p<0.05)$ artinya terdapat hubungan yang signifikan antara harga diri dengan depresi pasien HIVIAIDS dengan nilai korelasi $r=0.603(0.56-1,00=$ kuat) yang artinya hubungan kuat, dimana semakin semakin tinggi harga diri pasien maka semakin ringan depresi pasien HIVIAIDS di RSUP H. Adam Malik Medan.

Hasil penelitian ini menunjukkan bahwa harga diri merupakan salah satu faktor pendukung dalam mengatasi depresi yang di alami pasien HIVIAIDS. Menurut (Cutrona, 2014) dukungan konkrit berkaitan dengan tindakan langsung pada kebutuhan sehari- 
Vol. 11 No. 012020

e-issn : 2622-0148, p-issn : 2087-0035

hari, misalnya kesehatan penderita HIV dalam hal kebutuhan makan dan minum, istirahat, serta terhindarnya penderita dari kelelahan. Dukungan tersebut dapat diberikan sehari-hari oleh anggota keluarga, sehingga dukungan ini mudah diaplikasikan atau diterapkan anggota keluarga yang tinggal bersama dalam satu rumah dengan ODHA.

Penelitian lain yang dilakukan oleh (Fatmawati, 2018) dengan judul Hubungan Dukungan Keluarga Dan Depresi Pada ODHA di Kebumen didapatkan pvalue $=0,000(<0,05)$ dengan nilai $r=-0,588$ yang artinya ada hubungan antara variabel dukungan keluarga dengan variabel depresi. Semakin tinggi dukungan keluarga yang diperoleh ODHA, maka semakin rendah depresi pada ODHA. Sebaliknya, semakin rendah dukungan keluarga yang diperoleh ODHA, maka semakin tinggi depresi pada pasien ODHA. Dengan demikian, hipotesis yang diajukan dalam penelitian ini diterima.

Peneliti berasumsi bahwa harga diri yang tinggi sangat erat hubungannya dengan tingkat depresi pasien HIVIAIDS. Ketika harga diri tinggi maka tingkat depresi semakin ringan, sehingga dalam menjalani perawatan di RSUP H. Adam Malik merasa nyaman, aman dan bisa diterima dimasyarakat serta menjalani pengobatan dengan baik.

\section{KESIMPULAN}

Berdasarkan hasil penelitian terhadap karakteristik demografi yang dilakukan oleh peneliti di RSUP $\mathrm{H}$. Adam Malik terhadap 31 orang responden, diperoleh data yakni rata-rata jenis kelamin mayoritas laki-laki sebanyak 23 responden $(77,4 \%)$, usia mayoritas 21 40 tahun sebanyak 28 responden $(90,3 \%)$, dan status kawin mayoritas menikah sebanyak 19 responden (61,3\%). Harga diri pasien HIVIAIDS di RSUP $H$. Adam Malik mayoritas tinggi, depresi pasien HIVIAIDS di RSUP H. Adam Malik mayoritas ringan, terdapat hubungan yang signifikan antara harga diri dengan depresi pasien HIVIAIDS di RSUP $\mathrm{H}$. Adam Malik dengan nilai $p$ value $=0.000$ dengan kekuatan hubungan $r=0.603$.

\section{DAFTAR PUSTAKA}

Benerjee \& Sharma. (2007). Hubungan Harga Diri dengan Perilaku Seksual pada Penderita HIV AIDS di Kabupaten Indramayu. Jurnal Pendidikan Keperawatan Indonesia, 3(2). https://doi.org/10.17509/jpki.v3i2.9416

Cutrona. (2014). Kebijakan Pengendalian HIVIAIDS di Denpasar. Kesmas: National Public Health Journal, 8(1), 45. https://doi.org/10.21109/kesmas.v8i1.341

Fatmawati. (2018). Pengetahuan dan Sikap Perempuan yang Sudah Menikah Terhadap Pencegahan Penularan Human Immunodeficiency Virus/Acquired Immune Deficiency Syndrome (HIVIAIDS). Jurnal Aisyah : Jurnal IImu Kesehatan, 3(2), 153-162. https://doi.org/10.30604/jika.v3i2.130

Hapsari, Elyana., Sarjana, Widodo., Sofro, M. (2016) 'Hubungan Tingkat Depresi dengan Kualitas Hidup Pasien HIVIAIDS di RSUP dr. Kariadi Semarang', Jurnal Kedokteran Diponegoro, 5(4), pp. 737-750.

Haryanto, Wahyuningsih, H. D. and Nandiroh, S. (2015) 'Sistem Deteksi Gangguan Depresi Pada Anak-anak dan Remaja', Jurnal IImiah Teknik Industri, 14(2), pp. 142-152. Available at: http://journals.ums.ac.id/index.php/jiti/article/view/998.

Ibrahim, K. et al. (2017) 'Hubungan antara Fatigue , Jumlah CD4, dan Kadar Hemoglobin pada Pasien yang Terinfeksi Human Immunodeficiency Virus ( HIV ) The Correlation of Between Fatigue, CD4 Cell Count, and Hemoglobin Level among HIV / AIDS Patients', Jkp, 5(3), pp. 271-280.

Kanniappana et al,. (2007). Artikel Penelitian Kejadian Gangguan Depresi pada Penderita HIV / AIDS yang Mengunjungi Poli VCT RSUP Dr. M . Djamil Padang Periode. Jurnal Kesehatan Andalas, 3(2), 2011-2014.

Li, et, al. (2006). Perilaku Perawat Terhadap Orang Dengan Hiv/Aids Di Rumah Sakit Dan Puskesmas. Jurnal Keperawatan Indonesia, 14(2), 127-132. https://doi.org/10.7454/jki.v14i2.320

Maharani, R. (2014) 'Stigma dan Diskriminasi Orang Dengan HIV / AIDS ( ODHA ) pada Pelayanan Kesehatan di Kota Pekanbaru Tahun 2014 Stigmatization and Discrimination People Living With HIV / AIDS ( PLWHA ) At Pekanbaru Health Service In 2014', 2(5), pp. 225-232.

Marsasina, A. and Fitrikasari, A. (2016) 'Gambaran Dan Hubungan Tingkat Depresi Dengan Faktor-Faktor Yang 
Mempengaruhi Pada Pasien Rawat Jalan Puskesmas ( Studi Deskriptif Analitik Di Puskesmas Halmahera Semarang )', Jurnal Kedokteran Diponegoro, 5(4), pp. 440-450.

Rahmawati, L., Arneliwati and Elita, V. (2015) 'Relationship Between Family Support and Level of Depression Among Adolescents in Prison', Jom, 2(2), pp. 1221-1230. doi: 10.1002/9780470775097.ch13.

Kemenkes RI. (2017) 'Kementerian Kesehatan Repoblik Indonesia', Laporan Perkembangan HIV-AIDS.

Riskesdas. (2017). Hubungan Harga Diri dengan Perilaku Seksual pada Penderita HIV AIDS di Kabupaten Indramayu. Jurnal Pendidikan Keperawatan Indonesia, 3(2), 131. https://doi.org/10.17509/jpki.v3i2.9416

Siboro. (2013). PENCEGAHAN HIV / AIDS OLEH PEREMPUAN orang dengan HIV memudahkan terjadinya infeksi, sehingga menyebabkan timbulnya AIDS Di Provinsi Riau, terjadi kecendrungan didasarai pengetahuan . Hal ini sesuai dengan penelitian Muflihah , ( 2016) terdapat perbeda. 8(1).

Sternke. (2010). Stigma terhadap Orang dengan HIVIAIDS (ODHA) sebagai Hambatan ... (IIfan Ardani dan Sri Handayani) Stigma terhadap Orang dengan HIVIAIDS (ODHA) sebagai Hambatan Pencarian Pengobatan: Studi Kasus pada Pecandu Narkoba Suntik di Jakarta HIVIAIDS RELATED STIG. 81-88. https://doi.org/10.22435/bpk.v45i2.6042.81-88

UNAIDS (2017) Global HIV Statistics', Fact sheet, p. 6. Available at: http://www.unaids.org/en/resources/fact-sheet.

Unnikrishnan dkk. (2012). Artikel Penelitian Kejadian Gangguan Depresi pada Penderita HIV / AIDS yang Mengunjungi Poli VCT RSUP Dr . M . Djamil Padang Periode. Jurnal Kesehatan Andalas, 3(2), 2011-2014.

Utami, A. W., Liza, R. G. and Ashal, T. (2018) 'Hubungan Kemungkinan Depresi dengan Kualitas Hidup pada Lanjut Usia di Kelurahan Surau Gadang Wilayah Kerja Puskesmas Nanggalo Padang', Jurnal Kesehatan Andalas, 7(3), pp. 417-423. Available at: http://jurnal.fk.unand.ac.id/index.php/jka/article/download/896/750.

Wahyuningsih S, Novianto WT, P. H. (2017) 'Implementasi kebijakan pencegahan dan penanggulangan Human Immunodeficiency/Acquired Immune Deficiency Syndrome (HIV/AIDS) di kota Surakarta', Jurnal Pasca Sarjana Hukum UNS, V(2), pp. 178-189.

Wandono, W. A. (2017) 'Upaya peningkatan harga diri rendah pada pasien depresi', Jurnal psikologi, 4, p. 2.

Widya Shari, W., S, S. and Emaliyawati, E. (2017) 'Emotional Freedom Techniques dan Tingkat Kecemasan Pasien yang akan Menjalani Percutaneous Coronary Intervention', Jurnal Keperawatan Padjadjaran, v2(n3), pp. 133-145. doi: 10.24198/jkp.v2n3.1.

Yaunin, Y., Afriant, R. and Hidayat, N. M. (2014) 'Artikel Penelitian Kejadian Gangguan Depresi pada Penderita HIV I AIDS yang Mengunjungi Poli VCT RSUP Dr . M . Djamil Padang Periode', Jurnal Kesehatan Andalas, 3(2), pp. 2011-2014. 